\title{
Chapter 15 \\ The Role of Science in Shaping Sustainable Business: Unilever Case Study
}

\author{
Sarah Sim, Henry King, and Edward Price
}

\begin{abstract}
Unilever is a leading example of a multinational company in the FastMoving Consumer Goods (FMCG) sector. Unilever has long been an advocate of sustainable business, using scientific assessment as the basis for its strategy and initiatives. Given its business, Life Cycle Assessment (LCA) is established within the company and there is a current focus on improving the methodology and scope of LCA. Recent developments include new approaches to fill data gaps for agricultural ingredients and new impact assessment methods for assessing land use change. We have also adapted LCA approaches to inform corporate strategy and to engage a broad range of stakeholders both within the company and outside. The most recent and significant example of this has been the use of product footprinting as an integral element of Unilever's Sustainable Living Plan (USLP); currently over 2000 products are footprinted annually across 14 countries.

LCA approaches will continue to play an important role in Unilever's strategy. However, there is an urgent need to develop more predictive, regional/global level approaches that take into account the limited availability of many earth resources, the non-linearity of certain impacts and the absolute limits of sustainability. Several conceptual systems-level frameworks and theories already exist, but the Planetary Boundary (PB) approach has been selected as the most promising for developments in data, modelling and contextualization of environmental assessment. We have identified the need for developments in informatics to exploit new data gathering approaches as well as new modelling initiatives utilizing Geographical Information Systems (GIS) mapping and 'big data' approaches. In particular, we see real value in developing a distinct and novel, 'PB-enabled' normative LCA approach to support product/service/sectorial decision-making.
\end{abstract}

Keywords Unilever sustainable living plan • Fast-moving consumer goods sector • FMCG • Life cycle assessment $\bullet$ Environmental footprinting • Earth systems science $\bullet$ Resilience science $\bullet$ Planetary boundaries $\bullet$ Ecosystem services

\footnotetext{
S. Sim $(\bowtie) \bullet H$. King $\bullet$ E. Price

Safety and Environmental Assurance Centre (SEAC), Unilever,

Colworth Park, Sharnbrook, Bedford MK44 1LQ, UK

e-mail: sarah.sim@unilever.com 


\section{Introduction}

Unilever is a Fast Moving Consumer Goods (FMCG) company with over 400 brands, operations in nearly 100 countries and sales in nearly every country in the world. Our products (foods, beverages, ice cream, home and personal care) are used 2 billion times a day in over half the households on the planet. Our strategy for sustainable growth sets out a vision for leveraging this global reach to improve health and well-being, reduce environmental impacts and enhance livelihoods. Unilever has long been a pioneer of sustainability, and throughout this journey, science has been the foundation for the company's sustainability strategy and initiatives. As such, the focus of this chapter is not the business case for sustainability in Unilever (which can be found in Bell (2013a, b); Lingard (2012)), but an illustration of how science has helped inform and shape the company's thinking on sustainability so far and also how we will continue to use science to help us think about future challenges.

To date, Unilever has relied on scientific methods based around Life Cycle Assessment (LCA) to guide and inform our sustainability decision-making and such approaches will continue to have an important role to play. However, LCA does not address all relevant environmental impacts; nor does it deal with each impact category in an equally robust way. Therefore, there is an urgent need to develop more predictive approaches that take into account the limited availability of many resources, the non-linearity of certain impacts and the absolute nature of sustainability as articulated in the planetary boundary concept.

\section{The Journey So Far}

Life cycle assessment (LCA) is the preferred tool for many organizations to help them understand the impacts and performance of their products and services in a rigorous and scientific manner (Baitz et al. 2013). The LCA methodology was codified in the late 1980s/early 1990s through the work of SETAC and ISO. However, LCA is not a static tool and it is continually being evolved and improved to reflect new science and to expand the robustness and scope of the environmental impact assessment.

The flexibility of the LCA concept is one of its strengths; in Unilever, we have exploited this feature and in doing so helped inform and shape our environmental strategy over the past 20 years (Fig. 15.1). In the mid-1990s, Unilever developed the Overall Business Impact Assessment (OBIA) approach (Clift and Wright 2000) as a means to scientifically identify our priority environmental impacts and to inform the selection of key sustainability programs. Unlike traditional LCA which focuses on single systems, usually products, the OBIA approach can be used to assess the effects of all the individual products produced by a business for a given period of time, typically 1 year. The potential environmental impacts of the business are 


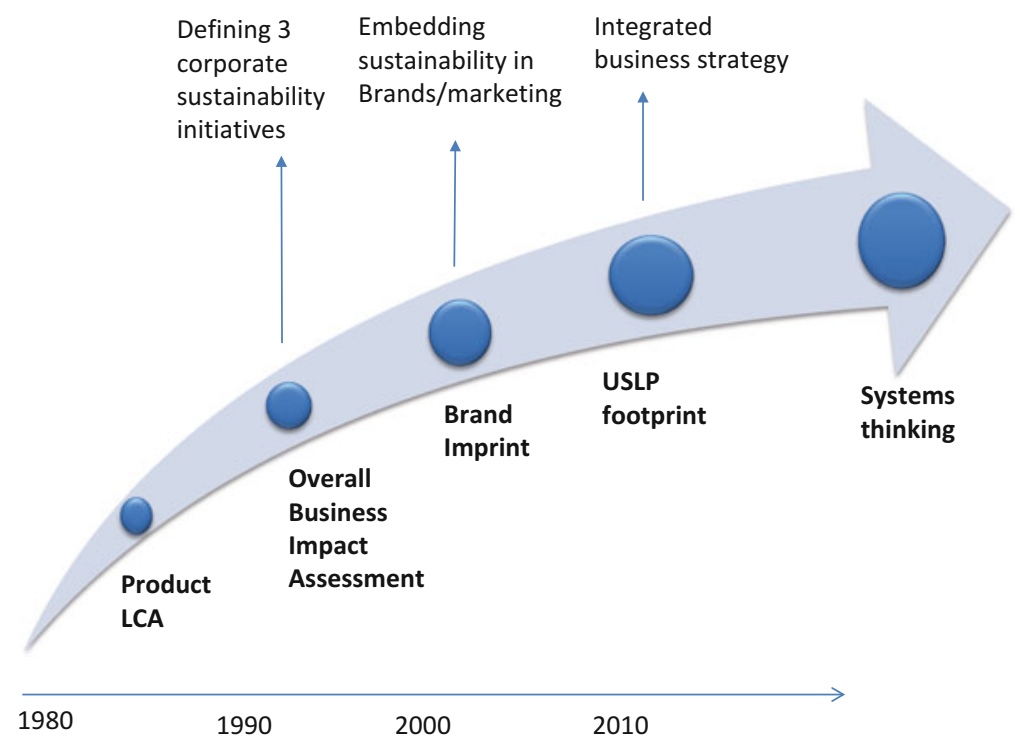

Fig. 15.1 Evolving development and application of environmental sustainability science within Unilever

presented as a profile or imprint and contributions are scaled (normalized) against annual global totals for each of the indicators and the economic size of the business (Clift and Wright 2000). By comparing the potential environmental impacts of a business to the economic size of the business, the OBIA approach helped to identify those areas where most benefit to the global environment can be achieved. The insights arising from the application of OBIA led to Unilever focusing on three sustainability themes in the late 1990s and early 2000s, namely sustainable fisheries, including the co-creation of the Marine Stewardship Council together with WWF (Constance and Bonanno 2000), the Sustainable Agriculture Initiative (Unilever 2010) and the creation of institutions such as the Roundtable for Sustainable Palm Oil and the Sustainable Water Initiative.

Unilever continues to innovatively develop and apply LCA and life cycle thinking to help inform strategy and to engage a broader range of stakeholders both within the company and outside. At a product level, recent method developments and applications have included new approaches: to fill data gaps in agricultural data (Milà i Canals et al. 2011; Roches et al. 2010; Nemecek et al. 2012); to better represent the impacts arising from land use change (Flynn et al. 2012; Milà i Canals et al. 2013); to better represent the impacts arising from product disposal (Muñoz et al. 2013); and the application of new methods for assessing impacts related to water (Jefferies et al. 2012 and Van Hoof et al. 2011). In addition, we have developed approaches to conduct brand/portfolio footprints with examples of Knorr and Ben \& Jerry's (Garcia Suarez et al. 2008; Milà i Canals et al. 2010). LCA also formed one of the elements of the innovative Brand Imprint process that Unilever 
Fig. 15.2 Unilever sustainable living plan

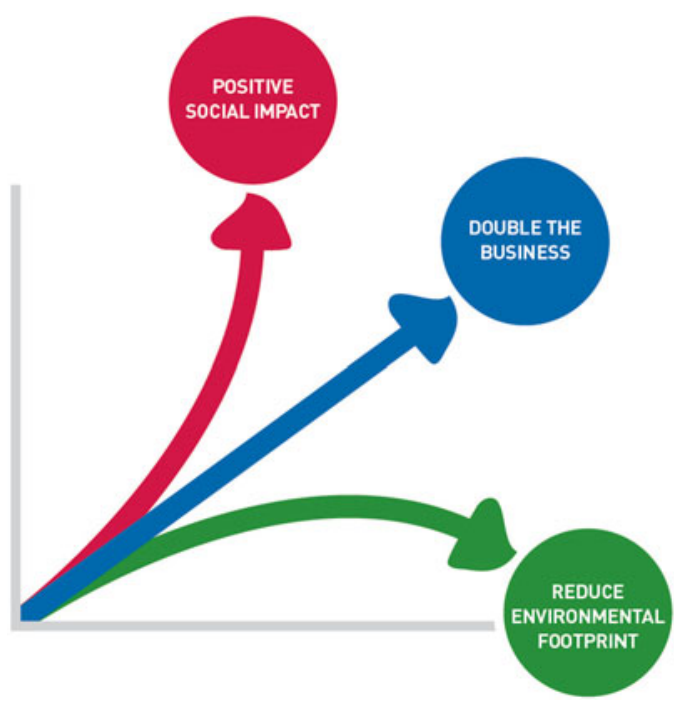

deployed with its Brand teams to help them understand the sustainability impacts and issues of their brands and to identify sustainability marketing opportunities in the late 2000s (Gowland 2009).

The most recent and significant example of the use of the LCA approach to guide sustainability strategy has been the use of product footprinting as an integral element of Unilever's Sustainable Living Plan (USLP) (Rigarlsford et al. 2010; UNEP 2015). The USLP footprint, which is an example of an organizational LCA (UNEP 2015 ) is based on a streamlined process that involves the definition of representative countries and products. Fourteen countries were selected on the basis of business parameters (e.g. annual sales and consumer habits) and environmental ones (e.g. carbon intensity of the electricity grid, waste management infrastructure and water scarcity). The business and sales in each country are then described by a series of representative products. Currently over 2000 products are footprinted annually and one of the key USLP objectives is to decouple business growth in sales from an increase in the footprint (Fig. 15.2).

\section{Looking to the Future}

As outlined in the previous section, to date our ability to think about sustainability has mostly focused around classical LCA, but we recognize the existence of global environmental limits; the earth's systems are not behaving as we have designed our economic and social systems. 'What is becoming apparent is that earlier assumptions about the stability, linearity, and reversibility of changes in ecosystems and the Earth systems fell short of what actually happens' (Whiteman et al. 2013). Assessment of corporate decisions in this context cannot be wholly facilitated by 


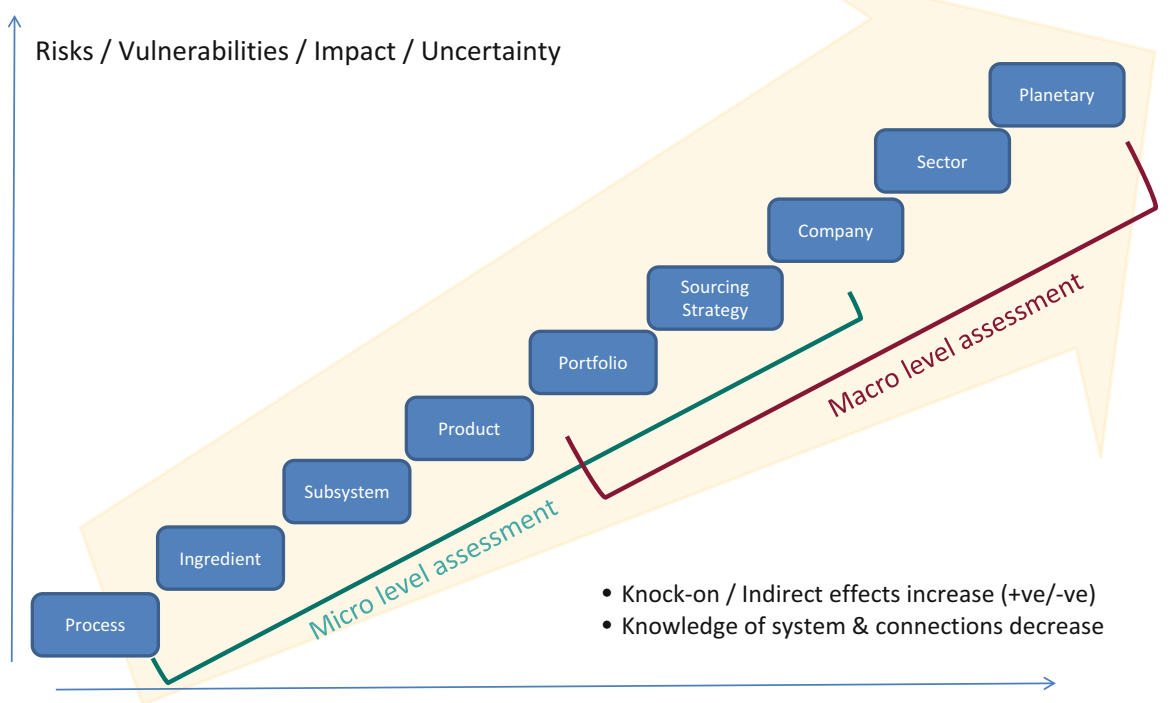

Fig. 15.3 Systems thinking - implications for method development and data

traditional LCA approaches. Though these remain important, their focus on ecoefficiency and relative sustainability will not be sufficient.

The refresh of Unilever's Sustainable Living Plan (USLP) in 2014 (Unilever 2014) articulates a desire to drive transformational change. There are three particular aspects to this: (1) helping to eliminate deforestation; (2) championing sustainable agriculture and smallholder farmers and (3) improving water, sanitation and hygiene (WaSH). This marks the start of a move towards more holistic, systemslevel analysis and action to achieve a decoupling of growth and impact. Systemsthinking requires new concepts, approaches, methods and tools. These need to be predictive, point to early warning signals or non-linear relationships between growth and environmental impacts (Biggs et al. 2009; Barnosky et al. 2012; Sheffer et al. 2009, 2012; Wang et al. 2012), be spatially resolved and operational at different scales of decision-making, but particularly portfolio, company and sectorial decisions (Fig. 15.3). Whilst clearly a 'tall order' when considering also the urgency with which we must act, Unilever has already begun efforts in this direction, for example, working with the Natural Capital Project at Stanford University to develop methodologies to help us understand the spatial dependency of Biodiversity and Ecosystem Services (BES) impacts associated with large scale agricultural expansion (as implied by the large and converging demand on agricultural raw materials from the foods, chemicals, energy and textile sectors). The research was set to explore possible nonlinear changes in environmental impacts which may arise from different amounts and spatial configurations of land use change, and which may be affected by corporate strategic sourcing decisions (Chaplin-Kramer et al. 2015). 
The need for such systems thinking and macro-level approaches, enabling us to predict and avoid unintended environmental consequences of growth and strategic choices (as discussed in Chap. 2), is amply illustrated by the example of biofuels. 'IPCC(2007) highlighted the large potential for biofuels to meet the growing energy needs as well as contributing to GHG emissions reduction, especially in the transportation sector. Escalating oil prices and the uncertainty about sustained oil supplies further added to the growing interest on biofuels' (Ravindranath et al. 2009). As such, a number of governments developed policies and financial incentives to encourage the production and use of biofuels. Unfortunately, large scale expansion of biofuel crops has led to land use change (LUC), notably the conversion of natural lands such as peatlands, forests and grasslands to the production of biofuel crops. 'Studies have shown that the possible GHG emissions from the induced LUC can substantially influence the climate benefit of biofuels production and use (Leemans et al. 1996; Schlamadinger et al. 2001; Fargione et al. 2008; Searchinger et al. 2008; Gibbs et al. 2008) [...] Fargione et al. (2008) shows that land-use conversion from native land-uses to biofuel crops leads consistently to significant GHG emissions and a negative carbon balance, or carbon-debt, for many years' (Ravindranath et al. 2009).

\subsection{Conceptual Basis for Developing Scientific Approaches}

Several conceptual systems-level frameworks and theories already exist, such as Ecological Footprint (Wackernagel and Rees 1996), Carrying Capacity (Rees and Wackernagal 1994) and 'Limits to Growth' (Meadows et al. 1972), but by far the most promising as a guiding concept for developments in data, modelling and contextualisation of environmental assessment is the Planetary Boundaries (PB) concept (Rockström et al. 2009a, b; Steffen et al. 2015). This concept stands out for a number of reasons:

1. The positive framing of a 'safe operating space' or an 'earth system stability domain' is helpful in a corporate innovation context. Planetary Boundaries firmly establishes the principle of 'absolute sustainability', attempting to set limits on how much impact or change can be tolerated in various PB categories before boundaries are transgressed and the Earth system moves outside of the set of parameters that are deemed 'safe' for humanity (into a 'danger zone') and beyond which global change is likely to have profound negative consequences for us. However, unlike other concepts such as 'Limits to Growth', it does not make assumptions about human ingenuity in terms of technology. As noted by Steffen et al. (2015), 'the PB approach is embedded in this emerging social context [rapid increase in human pressures on the planet], but it does not suggest how to manoeuvre within the safe operating space in the quest for global sustainability.' Rather we can view PB as presenting the context for transformative innovation. 
2. For Unilever specifically, there is a strong connection between this framing and the USLP transformational change agenda, particularly zero net deforestation (principally aligned to the land system change boundary) and improving water, sanitation and hygiene (WaSH) (particularly aligned to the biogeochemical flow and freshwater boundaries) (see Hague 2014).

3. The PB focus and framing also encourages predictive assessment, as opposed to descriptive or retrospective assessment, since the idea is to recognise the approach to boundaries so as to find 'risk-reducing interventions' (Steffen et al. 2015) and avoid transgressing the boundaries.

4. Planetary boundaries has received strong interest (with more than 60 peerreviewed papers on the subject since the seminal Rockström et al. paper in 2009a) and reasonably widespread acceptance, due to its robust empirical base which draws on both Earth System and Resilience Science. Clearly there is potential to improve quantification for all nine PB categories and efforts are ongoing in this regard (Carpenter and Bennett 2011; de Vries et al. 2013; Gerten et al. 2013; Mace et al. 2014), but 'the approach guarantee[s] a higher degree of consistency and meaningful aggregation (commensurability) than composite indices' (Whiteman et al. 2013) such as the 'Ecological Footprint [...] which fail to fulfil fundamental scientific requirements of validity and reliability (i.e. normalization, weighting, and aggregation), and reveal a high degree of arbitrariness' (Böhringer and Jochem 2007, in Whiteman et al. 2013).

5. Finally, the concept aims to hold focus on these nine categories simultaneously, recognising the inter-dependencies between them: this imposes limits to tradeoffs in that temporal and spatial trade-offs could be considered within a PB category but not between them (Murphy et al. in prep). Clearly this implies considerable space for the development of multi-disciplinary approaches.

The planetary boundary (PB) concept is increasingly being accepted as a science basis for understanding sustainability in business and government policy contexts (e.g. EU Sustainable Foods Policy development, WBCSD Action 2020), although measurement and analysis of the actions advocated is required to provide assurance that actions will and indeed are leading to the right outcomes; or, otherwise stated, 'to quantitatively measure the role of companies within the decline [or maintenance] of Earth systems' (Whiteman et al. 2013). 'We therefore need more studies that analyse how the micro role of firms and industries interacts with a macro-view of the world informed by system dynamics in order to better address environmental externalities (Whiteman et al. 2013). Indeed this is the challenge: PBs are planetaryscale and "conceptual" and we need to find ways in which they can be made operational at various geographical scales (local, regional and global) (see for example, Nykvist et al. 2013; Cole et al. 2014; Dearing et al. 2014) but particularly decisionmaking scales (product, portfolio, company and industry sector). This is where scientific advance aligned to the PB concept is required. An early attempt can be seen at the sectorial scale with the 'Mind the Science, Mind the Gap project' (CDP et al. 2014), which proposes guidance on methodology to set science based GHG emissions reduction targets in line with a $2{ }^{\circ} \mathrm{C}$ decarbonisation pathway. 


\subsection{Applying the Planetary Boundaries Approach for Business Decision-Making}

There are, however, few such examples since the operationalization of PB is still immature. We argue for further methodological development to build on existing data gathering and modelling initiatives using new GIS-based mapping and 'big data' approaches e.g. Future Earth (www.futureearth.org) and the UK Centre for Agricultural Innovation in the area of agri-informatics and sustainability metrics (White 2015) in order to improve our ability to measure the PBs appropriately, but to do so in a 'solution-focused' frame. That is to say that even when risks, impacts or transgression of the PBs are uncertain, we still need approaches that will help to move the PB approach into day-to-day decisions as a matter of priority. For this reason, towards the end of 2014, Unilever's Safety and Environmental Assurance Centre (SEAC) and the Centre for Environmental Strategy, University of Surrey, cohosted an expert workshop on this topic. The outcome is a 'roadmap' for how operationalizing the PB concept can be approached in practical decision-making. This is a 'forward looking' agenda for research and implementation in which we will propose a possible framework for progress (Murphy et al. in prep). In summary, the agenda includes the need for: (1) additional science to underpin each boundary, but particularly the biodiversity (now revised to 'biosphere integrity' in Steffen et al. (2015)), chemical pollution (now 'novel entities' in Steffen et al. (2015)) and freshwater boundaries'; (2) development or identification of 'rules of thumb' that can be implemented rapidly; (3) normative debate for example around equity, human/societal values, governance, land use contests, lifestyle changes, etc. and; (4) tools for integrating the science in decision-making contexts. In particular, we see real value in developing a distinct and novel, 'PB-enabled' normative LCA approach to support the adoption of the PB concept in product/service/sectorial decision-making; this would be a complement to, and not a replacement of, existing LCA uses.

\section{Conclusion}

It is evident that Unilever's pioneering position in regards to sustainability is firmly rooted in our innovative application of, and commitment to, environmental sustainability science. This has helped inform and shape the company's thinking on

\footnotetext{
${ }^{1}$ These boundary categories were chosen as the focus for the workshop as they are of particular relevance to Unilever because of the types of products the company designs and markets (acknowledging of course that due to inter-linkages between PB categories, all are relevant in some way or another to companies such as Unilever). In addition, we believe that (better) definition and consensus of the planetary boundary for these three is particularly important since the boundaries are either missing entirely (chemical pollution/novel entities), challenging on the basis of scale (regional vs global) (all three), or indeed now considered to be 'core PBs' in a 'two level hierarchy of boundaries' (biodiversity/biosphere integrity) (Steffen et al. 2015).
} 
sustainability and we will continue to use science to help us address future challenges. Currently, systems thinking remains in the margins of scientific development, but increasingly this needs to be brought to the fore so that large companies such as Unilever, as well as governments, are better equipped to make choices that can drive transformational change. This implies even more intensive cross-disciplinary activity, merging elements from Environmental Sustainability Science, LCA, Earth Systems Science, Resilience Science and Economics for more holistic insights and business/policy relevant assessment tools. The emerging developments in big data, informatics, and the deployment of imaging technologies and information systems to visualize earth systems will facilitate the move towards a more holistic understanding of environmental impacts and the sustainable management of Earth's resources.

Open Access This chapter is distributed under the terms of the Creative Commons Attribution Noncommercial License, which permits any noncommercial use, distribution, and reproduction in any medium, provided the original author(s) and source are credited.

\section{References}

Baitz, M., Albrecht, S., Brauner, E., Broadbent, C., Castellan, G., Conrath, P., Fava, J., Finkbeiner, M., Fischer, M., Fullanai Palmer, P., Krinke, S., Leroy, C., Loebel, O., McKeown, P., Mersiowsky, I., Möginger, B., Pfaadt, M., Rebitzer, G., Rother, E., Ruhland, K., Schanssema, A., \& Tikana, L. (2013). LCAs theory and practice: Like ebony and ivory living in perfect harmony. International Journal of Life Cycle Assessment, 18, 5-13.

Barnosky, A. D., Hadly, E. A., Bascompte, J., Berlow, E. L., Brown, J. H., Fortelius, M., Getz, W. M., Harte, J., Hastings, A., Marquet, P. A., Martinez, N. D., Mooers, A., Roopnarine, P., Vermeij, G., Williams, J. W., Gillespie, R., Kitzes, J., Marshall, C., Matzke, N., Mindell, D. P., Revilla, E., \& Smith, A. B. (2012). Approaching a state shift in Earth's biosphere. Nature, 486(7401), 52-58.

Bell, G. (Interview by) (2013a). Doing well by doing good. Strategic Direction, 29(4), 38-40.

Bell, G. (Interview by) (2013b). Want to change the world? Think differently. Strategic Direction, 29(5), 36-39.

Biggs, R., Carpenter, S. R., \& Brock, W. A. (2009). Turning back from the brink: Detecting an impending regime shift in time to avert it. Proceedings of the National academy of Sciences of the United States of America, 106, 826-831. doi:10.1073/pnas.0811729106.

Böhringer, C., \& Jochem, P. E. P. (2007). Measuring the immeasurable - A survey of sustainability indices. Ecological Economics, 63, 1-8.

Carpenter, S. R., \& Bennett, E. M. (2011). Reconsideration of the planetary boundary for phosphorus. Environmental Research Letters, 6, 014009. doi:10.1088/1748-9326/6/1/014009.

CDP, GHGP, \& WWF. (2014, March). Mind the science, mind the gap. Concept Note. Retrieved January 30, 2015, from http://www.ghgprotocol.org/files/ghgp/Concept\%20Note\%20-\%20 MScienceMGap.pdf

Chaplin-Kramer, R., Sharp, R., Mandle, L., Sim, S., Johnson, J., Butnar, I., Milà i Canals, L., Eichelberger, B., Ramler, I., Mueller, C., McLachlan, N., Yousefi, A., King, H., \& Kareiva, P. (2015). Spatial patterns of agricultural expansion determine impacts on biodiversity and carbon storage. Proceedings of the National academy of Sciences of the United States of America, 112(24), 7402-7407. doi:10.1073/pnas.1406485112.

Clift, R., \& Wright, L. (2000). Relationships between environmental impacts and added value along the supply chain. Technological Forecasting and Social Change, 65, 281-295. 
Cole, M. J., Bailey, R. M., \& New, M. G. (2014). Tracking sustainable development with a national barometer for South Africa using downscaled "safe and just space" framework. Proceedings of the National academy of Sciences of the United States of America, 111(42), E4399-E4408. doi:10.1073/pnas.1400985111.

Constance, D. H., \& Bonanno, A. (2000, June). Regulating the global fisheries: The World Wildlife Fund, Unilever, and the Marine Stewardship Council. Agriculture and Human Values, 17(2), $125-139$.

De Vries, W., Kros, J., Kroeze, C., \& Seitzinger, S. P. (2013). Assessing planetary and regional nitrogen boundaries related to food security and adverse environmental impacts. Current Opinion in Environment. Sustainability, 5, 392-402. doi:10.1016/j.cosust.2013.07.004.

Dearing, J. A., Wang, R., Zhang, K., Dyke, J. G., Haberl, H., Hossain, M. S., Langdon, P. G., Lenton, T. M., Raworth, K., Brown, S., Carstensen, J., Cole, M. J., Cornell, S. E., Dawson, T. P., Doncaster, C. P., Eigenbrod, F., Flörke, M., Jeffers, E., Mackay, A. W., Nykvist, B., \& Poppy, G. M. (2014). Safe and just operating spaces for regional social-ecological systems. Global Environmental Change, 28, 227-238.

Fargione, J., Hill, J., Tilman, D., Polasky, S., \& Hawthorne, P. (2008). Land clearing and the biofuel carbon debt. Science 319, 1235. American Association for the Advancement of Science, New York/Washington DC.

Flynn, H. C., Milà i Canals, L., Keller, E., King, H., Sim, S., Hastings, A., \& Smith, P. (2012). Quantifying global greenhouse gas emissions from land-use change for crop production. Global Change Biology, 18(5), 1622-1635. doi:10.1111/j.1365-2486.2011.02618.x.

Garcia-Suarez, T., Sim, S., Mauser, A., \& Marshall, P. (2008, November 12-14). Greenhouse gas assessment of Ben \& Jerry's ice cream: Communicating their 'Climate Hoofprint.' Paper in the proceedings of the 6th international conference on life cycle assessment in the Agri-Food sector: Towards a sustainable management of the food chain. Zurich, Switzerland.

Gerten, D., Hoff, H., Rockstrom, J., Jagermeyr, J., Kummu, M., \& Pastor, A. V. (2013). Towards a revised planetary boundary for consumptive freshwater use: Role of environmental flow requirements. Current Opinion on Environmental Sustainability, 5, 551-558.

Gibbs, H. K., Johnston, M., Foley, J., Holloway, T., Monfreda, C., Ramankutty, N., \& Zaks, D. (2008). Carbon payback times for crop-based biofuel expansion in the tropics: The effects of changing yield and technology. Environmental Research Letters, 3, 034001 (10pp).

Gowland, S. (2009). Unilever's sustainable brand and business strategy. Melodies in marketing. Retrieved January 30, 2015, from http://www.melodiesinmarketing.com/2009/04/11/ unilever-sustainable-brand-lipton-knorr-dove

Hague, J. (2014). Building future sanitation models: A report prepared for the toilet board coalition, sponsored by Unilever. Retrieved January 30, 2015, from http://www.toiletboard.org/ media/downloads/6.pdf

IPCC. (2007). Mitigation of climate change: Technical summary. Geneva: Intergovernmental Panel on Climate Change.

Jefferies, D., Muñoz, I., Hodges, J., King, V. J., Aldaya, M., Ercin, A. E., Milà i Canals, L., \& Hoekstra, A. Y. (2012, September). Water footprint and life cycle assessment as approaches to assess potential impacts of products on water consumption. Key learning points from pilot studies on tea and margarine. Journal of Cleaner Production, 33, 155-166.

Leemans, R., van Amstel, A., Battjes, C., Kreilman, E., \& Toet, S. (1996). The land cover and carbon cycle consequences of large-scale utilizations of biomass as an energy source. Global Environmental Change, 4, 335-357.

Lingard, T. (2012). Unilever's strategic response to sustainable development and its implications for public affairs professionals. Journal of Public Affairs, 12, 224-229. doi:10.1002/pa.1436.

Mace, G. M., Reyers, B., Alkemade, R., Biggs, R., Chapin, F. S., III, Cornell, S. E., Díaz, S., Jennings, S., Leadley, P., Mumby, P. J., Purvis, A., Scholes, R. J., Seddon, A. W. R., Solan, M., Steffen, W., \& Woodward, G. (2014). Approaches to defining a planetary boundary for biodiversity. Global Environmental Change, 28, 289-297. doi:10.1016/j.gloenvcha.2014.07.009.

Meadows, D. H., Meadows, D. L., Randers, J., \& Behrens, W. W. (1972). Limits to growth. New York: New American Library. 
Milà i Canals, L., Sim, S., Garcia-Suarez, T., Neuer, G., Herstein, K., Kerr, C., Rigarlsford, G., \& King, H. (2010). Estimating the greenhouse gas footprint of Knorr. The International Journal of Life Cycle Assessment, 16(1), 150-158. doi:10.1007/s11367-010-0239-5.

Milà i Canals, L., Azapagic, A., Doka, G., Jefferies, D., King, H., Mutel, C., Nemecek, T., Roches, A., Sim, S., Stichnothe, H., Thoma, G., \& Williams, A. (2011). Approaches for addressing life cycle assessment data gaps for bio-based products. Journal of Industrial Ecology, 15(5), 707-725.

Milà i Canals, L., Rigarlsford, G., \& Sim, S. (2013). Land use impact assessment of margarine. Journal of Life Cycle Assessment, 18(6), 1265-1277.

Muñoz, I., Rigarlsford, G., Mila, I., Canals, L., \& King, H. (2013). Accounting for greenhouse gas emissions from the degradation of chemicals in the environment. International Journal of Life Cycle Assessment, 18(1), 252-262.

Murphy, R. J. et al. (in prep). Planetary boundaries as a basis for decision-making.

Nemecek, T., Weiler, K., Plassmann, K., Schnetzer, J., Gaillard, G., Jefferies, D., García-Suárez, T., King, H., \& Milà I Canals, L. (2012, August). Estimation of the variability in global warming potential of worldwide crop production using a modular extrapolation approach. Journal of Cleaner Production, 31, 106-117.

Nykvist, B., Persson, Å., Moberg, F., Persson, L., Cornell, S., \& Rockström, J. (2013, June). National Environmental Performance on Planetary Boundaries - A study for the Swedish Environmental Protection Agency. Report 6573.

Ravindranath, N. H., Manuvie, R., Fargione, J., Canadell, P., Berndes, G., Woods, J., Watson, H., \& Sathaye, J. (2009). SCOPE Biofuel Report. Chapter 4, GHG implications of land use and land conversion to biofuel crops. Retrieved January 30, 2015, from http://www.globalbioenergy.org/uploads/media/0810_Ravindranath_et_al_-_GHG_implications_of_land_use_and_ land_conversion_to_biofuel_crops.pdf

Rees, W., \& Wackernagel, M. (1994). Ecological footprints and appropriated carrying capacity: Measuring the natural capacity requirements of the human economy. In A. Jansson, M. Hammer, C. Folke, \& R. Costanza (Eds.), Investing in natural capital. Washington, DC: Island Press.

Rigarlsford, G., Garcia-Suarez, T., Milà i Canals, L., David, H., Sim, S., Unger, N., \& King, H. (2010, September 22-24). Estimating the greenhouse gas footprint of Unilever's food business. Presented at the 7th international conference on LCA in the agri-foods sector. Bari, Italy.

Roches, A., Nemecek, T., Gaillard, G., Plassmann, K., Sim, S., King, H., \& Milà i Canals, L. (2010). MEXALCA: A modular method for the extrapolation of crop LCA. The International Journal of Life Cycle Assessment, 15(8), 842-854. doi:10.1007/s11367-010-0209-y.

Rockström, J., Steffen, W., Noone, K., Persson, Å., Chapin, F. S., III, Lambin, E., Lenton, T. M., Scheffer, M., Folke, C., Schellnhuber, H., Nykvist, B., De Wit, C. A., Hughes, T., van der Leeuw, S., Rodhe, H., Sörlin, S., Snyder, P. K., Costanza, R., Svedin, U., Falkenmark, M., Karlberg, L., Corell, R. W., Fabry, V. J., Hansen, J., Walker, B., Liverman, D., Richardson, K., Crutzen, P., \& Foley, J. (2009a). A safe operating space for humanity. Nature, 461, 472-475.

Rockström, J., Steffen, W., Noone, K., Persson, A., Chapin, F. S., III, Lambin, E., Lenton, T. M., Scheffer, M., Folke, C., Schellnhuber, H., Nykvist, B., De Wit, C. A., Hughes, T., van der Leeuw, S., Rodhe, H., Sörlin, S., Snyder, P. K., Costanza, R., Svedin, U., Falkenmark, M., Karlberg, L., Corell, R. W., Fabry, V. J., Hansen, J., Walker, B., Liverman, D., Richardson, K., Crutzen, P., \& Foley, J. (2009b). Planetary boundaries: Exploring the safe operating space for humanity. Ecology and Society, 14(2), 32.

Scheffer, M., Bascompte, J., Brock, W. A., Brovkin, V., Carpenter, S. R., Dakos, V., Held, H., van Nes, E. H., Rietkerk, M., \& Sugihara, G. (2009). Early-warning signals for critical transitions. Nature, 461, 53-59. doi:10.1038/nature08227.

Scheffer, M., Carpenter, S. R., Lenton, T. M., Bascompte, J., Brock, W., Dakos, V., van de Koppel, J., van de Leemput, I. A., Levin, S. A., van Nes, E. H., Pascual, M., \& Vandermeer, J. (2012). Anticipating critical transitions. Science, 338, 344-34. doi:10.1126/science.1225244.

Schlamadinger, B., Grubb, M., Azar, C., Bauen, A., \& Berndes, G. (2001). Carbon sinks and biomass energy production: A study of linkages, options and implications. Climate Strategies: International Network for Climate Policy Analysis. London. 
Searchinger, T., Heimlich, R., Houghton, R. A., Dong, F., Elobeid, A., Fabiosa, J., Tokgoz, S., Hayes, D., \& Yu, T. H. (2008). Use of U.S. croplands for biofuels increases greenhouse gases through emissions from land-use change. Science, 319(5867), 1238-1240.

Steffen, W., Richardson, K., Rockström, J., Cornell, S. E., Fetzer, I., Bennett, E. M., Biggs, R., Carpenter, S. R., de Vries, W., de Wit, C. A., Folke, C., Gerten, D., Heinke, J., Mace, G. M., Persson, L. M., Ramanathan, V., Reyers, B., \& Sörlin, S. (2015). Planetary boundaries: Guiding human development on a changing planet. Science, 347(6223), 1259855. doi:10.1126/ science. 1259855 .

UNEP. (2015) Guidance on Organisational Life Cycle Assessment. Available at: http://www.lifecycleinitiative.org/wp-content/uploads/2015/04/o-lca_24.4.15-web.pdf

Unilever. (2014). Unilever sustainable living plan. Retrieved January 30, 2015, from http://www. unilever.co.uk/sustainable-living-2014/our-approach

Unilever Sustainable Agriculture Code. (2010). Retrieved January 30, 2015, from http://unilever. com/images/sd_Unilever_Sustainable_Agriculture_Code_2010_tcm13-216557.pdf

Van Hoof, G., Schowanek, D., Franceschini, H., \& Muñoz, I. (2011). Ecotoxicity impact assessment of laundry products: A comparison of USEtox and critical dilution volume approaches. International Journal of Life Cycle Assessment, 16(8), 803-818.

Wackernagel, M., \& Rees, W. (1996). Our ecological footprint: Reducing human impact on the earth. Gabriola Island: New Society Publishers. ISBN 0-86571-312-X.

Wang, R., Dearing, J. A., Langdon, P. G., Zhang, E., Yang, X., Dakos, V., \& Scheffer, M. (2012). Flickering gives early warning signals of a critical transition to a eutrophic lake state. Nature, 492, 419-422. doi:10.1038/nature11655.

White, S. (2015, January 02). Preferred Bidder selected for first centre for Agricultural Innovation Centre. Retrieved January 30, 2015, from https://agritech.blog.gov.uk/feed/atom/

Whiteman, G., Walker, B., \& Perego, P. (2013). Planetary boundaries: Ecological foundations for corporate sustainability. Journal of Management Studies, 50(2), 307-336. 